\title{
Managing Carious Lesions: Consensus Recommendations on Terminology
}

\author{
Advances in Dental Research \\ 2016, Vol. 28(2) 49-57 \\ (c) International \& American Associations \\ for Dental Research 2016 \\ Reprints and permissions: \\ sagepub.com/journalsPermissions.nav \\ DOI: 10.1 I 177/0022034516639276 \\ adr.sagepub.com
}

\author{
N.P.T. Innes', J.E. Frencken², L. Bjørndal', M. Maltz ${ }^{3}$, D.J. Manton ${ }^{5}$, \\ D. Ricketts ${ }^{6}$, K. Van Landuyt ${ }^{7}$, A. Banerjee ${ }^{8}$, G. Campus ${ }^{9}$, S. Doméjean ${ }^{10}$, \\ M. Fontana ${ }^{\prime \prime}$, S. Leal ${ }^{12}$, E. Lo ${ }^{13}$, V. Machiulskiene ${ }^{14}$, A. Schulte ${ }^{15}$, C. Splieth ${ }^{16}$, \\ A. Zandona ${ }^{17}$, and F. Schwendicke ${ }^{18}$
}

\begin{abstract}
Variation in the terminology used to describe clinical management of carious lesions has contributed to a lack of clarity in the scientific literature and beyond. In this article, the International Caries Consensus Collaboration presents I) issues around terminology, a scoping review of current words used in the literature for caries removal techniques, and 2) agreed terms and definitions, explaining how these were decided. Dental caries is the name of the disease, and the carious lesion is the consequence and manifestation of the disease- the signs or symptoms of the disease. The term dental caries management should be limited to situations involving control of the disease through preventive and noninvasive means at a patient level, whereas carious lesion management controls the disease symptoms at the tooth level. While it is not possible to directly relate the visual appearance of carious lesions' clinical manifestations to the histopathology, we have based the terminology around the clinical consequences of disease (soft, leathery, firm, and hard dentine). Approaches to carious tissue removal are defined: I) selective removal of carious tissue-including selective removal to soft dentine and selective removal to firm dentine; 2 ) stepwise removal-including stage I, selective removal to soft dentine, and stage 2, selective removal to firm dentine 6 to 12 mo later; and 3) nonselective removal to hard dentine-formerly known as complete caries removal (technique no longer recommended). Adoption of these terms, around managing dental caries and its sequelae, will facilitate improved understanding and communication among researchers and within dental educators and the wider clinical dentistry community.
\end{abstract}

Keywords: dental caries, excavation, minimally invasive dentistry, caries management, stepwise caries removal, nomenclature

\section{Introduction}

The International Caries Consensus Collaboration (ICCC), a group of 21 cariology experts from 12 countries, met in Leuven,
Belgium, in February 2015 to discuss issues of relevance to cariology researchers, dental educators, and the clinical dentistry community. The goal was to reach consensus on recommendations for managing carious lesions and the terminology

'Paediatric Dentistry, Dundee Dental Hospital and School, University of Dundee, Dundee, UK

${ }^{2}$ Department of Oral Function and Prosthetic Dentistry, College of Dental Sciences, Radboud University Medical Centre, Nijmegen, The Netherlands

${ }^{3}$ Department of Cariology and Endodontics, Faculty of Health and Medical Sciences, University of Copenhagen, Copenhagen, Denmark

${ }^{4}$ Department of Preventive and Social Dentistry, Faculty of Odontology, Federal University of Rio Grande do Sul, Porto Alegre, Brazil

${ }^{5}$ Melbourne Dental School, University of Melbourne, Melbourne, Australia

${ }^{6}$ Operative Dentistry, Fixed Prosthodontics and Endodontology, Dundee Dental Hospital and School, University of Dundee, Dundee, UK

${ }^{7}$ KULeuven BIOMAT, Department of Oral Health Sciences, University of Leuven and Dentistry University Hospitals Leuven, Leuven, Belgium

${ }^{8}$ Conservative and MI Dentistry, King's College London Dental Institute, London, UK

${ }^{9}$ Department of Surgery, Microsurgery and Medicine Sciences, School of Dentistry, University of Sassari, Sassari, Italy; WHO Collaborating Centre for Epidemiology and Community Dentistry, University of Milan, Milan, Italy

${ }^{10} \mathrm{CHU}$ Clermont-Ferrand, Service d'Odontologie, Hôtel-Dieu, Clermont-Ferrand, France; Univ Clermont I, UFR d'Odontologie, Clermont-Ferrand, France; Centre de Recherche en Odontologie Clinique EA 4847, Clermont-Ferrand, France

"Department of Cariology, Restorative Sciences and Endodontics, School of Dentistry, University of Michigan; Ann Arbor, MI, USA

${ }^{12}$ Department of Dentistry, Faculty of Health Sciences, University of Brasília, Brasília, Brazil

${ }^{13}$ Faculty of Dentistry, University of Hong Kong, Hong Kong, China

${ }^{14}$ Department of Dental and Oral Pathology, Faculty of Odontology, Lithuanian University of Health Sciences, Kaunas, Lithuania

${ }^{15}$ Department of Special Care Dentistry, Faculty of Health, University of Witten/Herdecke, Witten, Germany

${ }^{16}$ Preventive and Pediatric Dentistry, University of Greifswald, Greifswald, Germany

${ }^{17}$ Department of Operative Dentistry, University of North Carolina at Chapel Hill School of Dentistry, Chapel Hill, NC, USA

${ }^{18}$ Department of Operative and Preventive Dentistry, Charité-Universitätsmedizin Berlin, Berlin, Germany

Corresponding Author:

N.P.T. Innes, Paediatric Dentistry, Dundee Dental Hospital and School, University of Dundee, Park Place, Dundee, DDI 4HN, UK.

Email: n.p.innes@dundee.ac.uk 
around this management, based on the best current scientific evidence, through discussion and then consultation. In 2004, a series of papers were published that related to the outcomes of an International Consensus Workshop on Caries Clinical Trials (Pitts and Stamm 2004), its first goal being to "critically review modern caries definitions and measurement concepts." Definitions, concepts, and terminology as well as evidence to support newer approaches for treating carious lesions have advanced since then, and the ICCC felt a need to clarify them based on contemporary evidence and expertise.

Dental caries is the name of a disease where an ecologic shift within the dental biofilm environment, driven by frequent access to fermentable dietary carbohydrates, leads to a move from a balanced population of microorganisms of low cariogenicity to a microbiological population of high cariogenicity (more aciduric and acidogenic) and to an increased production of organic acids. This promotes dental hard tissue net mineral loss and results in a carious lesion (Fejerskov and Larsen 2015).

This report from the ICCC deals with the terminology around carious tissue removal, lays out the background to the issues around terminology, including a scoping review, and the initial areas that were agreed to allow progression through the topic. We suggest a suite of terms and definitions based on current procedures and best evidence, and we explain how these decisions were made. The report defines generic dental caries terms (Table 1) where there has been confusion, under the following groupings:

1) No removal of carious tissue

2) Selective removal

3) Stepwise removal

4) Nonselective removal of carious tissue

One further aim is to make the nomenclature as future proof as possible by taking into account the direction in which cariology is moving.

\section{Background}

One hundred fifty years ago, complete removal of all traces of carious tooth tissue within a carious lesion was considered the gold standard, with the added "extension for prevention" tenet being invoked to ensure that restoration margins were placed on areas of the tooth that are less vulnerable to caries. Advances in the field of cariology regarding the biofilm, with improvement in materials, have challenged this perspective. There has been an evolution gathering speed over recent decades, away from removing all signs of carious tissue in a tooth and toward a more minimally invasive approach (Elderton 1993; Frencken et al. 2012; Banerjee and Doméjean 2013). Indeed, a paradigm shift in carious lesion treatment has occurred, where it is now accepted that it is only infected, not affected, dentine that needs to be removed (Fusayama 1997). Choices for managing a carious lesion cover a spectrum of options - from complete surgical excision, where no part of the visible carious tissue is left, by the clinician, in the tooth before a restoration is placed, to the opposite extreme, where none of the carious tissue is removed at all and noninvasive methods are used to prevent progression of the lesion (Ricketts et al. 2013; Green et al. 2015).

The alternatives to "conventional complete caries removal" have been tested by different research groups over the last few decades through clinical trials, and they have been adopted, to varying degrees, as standard treatment by dental schools and clinicians in many countries (Innes and Evans 2013; Frencken 2014; Kidd et al. 2015). However, there is inconsistency in the terminology for, and definitions that lie behind, these approaches. These inconsistencies have developed naturally alongside the investigation of new interventions and as a result of different research groups describing and naming interventions as they have been investigated. As is common in evolving fields of research, some of this research has taken place in parallel. As such, different terms have evolved, partly because of the sensitive nature of research development but also simply as a result of a scarcity of opportunity for discussion. The lack of overt and planned communication within the research, teaching, and clinical practice communities has resulted in some of the variations now seen in use of terminology and procedural definitions. For some procedures that seem to be similar (based on the descriptions in research papers), different groups use distinctly different names. One particular definition of a procedure can have several names-for example, Franzon et al. (2014) use "one-step excavation" to describe a result similar to that of Hesse et al. (2014) for partial caries removal: "excavation [to] hardened, dried dentin with a leathery consistency." Groups that work together may know what they are referring to, but the wider audiences can misinterpret what is being said - especially where a single word is used to designate a procedure, without further opportunity to describe what is meant. Conversely but leading to equally confusing scenarios, for procedures that seem to differ from their descriptions, the same name or similar ones are used by different groups. So, one name holds a variety of definitions. For example, with selective caries removal, Maltz et al. (2012) describe this as "partial removal of the soft carious tissue from the cavity floor by hand excavator (only disorganized dentine was removed)." However, in their protocol step that involves partial caries removal, Hesse and coworkers (2014) state that the "caries lesion [was] completely removed in the enamel/dentin junction, and dentinal caries lesion partially removed with hand instruments until the dentin started to become 'firm and leathery." In addition, for the first stage of stepwise caries removal, Bjørndal et al. (2010) talk about "removal of the superficial necrotic and demineralized dentin with complete excavation of the peripheral demineralized dentin, avoiding excavation close to the pulp. When a temporary restoration could be properly placed no further excavation was carried out, leaving soft, wet, and discoloured dentin centrally on the pulpal wall."

To communicate successfully and concisely, researchers, clinicians, and educators need to use consistent terminology. This will help to ensure that carious tissue removal procedures are described unambiguously. One example of a clear description 
Table I. Overview of Carious Tissue Removal/Management Terminology and Groupings.

\begin{tabular}{|c|c|c|c|}
\hline $\begin{array}{l}\text { Type of Carious } \\
\text { Tissue Removal }\end{array}$ & Previous Names / Further Detail & Short Descriptions & $\begin{array}{l}\text { Indications for Noncleansable } \\
\text { Dentine Carious Lesions }\end{array}$ \\
\hline $\begin{array}{l}\text { Atraumatic } \\
\text { restorative } \\
\text { treatment (ART) }\end{array}$ & $\begin{array}{l}\text { A specific technique for carious } \\
\text { lesion management using hand } \\
\text { instruments only }\end{array}$ & $\begin{array}{l}\text { - Carious tissue removal using hand instruments } \\
\text { only } \\
\text { - Pulpally, excavate to firm dentine in shallow } \\
\text { lesions and to soft dentine in deep lesions } \\
\text { - Restore cavity and seal available pits and fissures } \\
\text { with adhesive dental material, usually a high- } \\
\text { viscosity glass ionomer cement }\end{array}$ & $\begin{array}{l}\text { Primary and permanent teeth } \\
\text { Shallow and moderate }{ }^{\text {a dentine }} \\
\text { carious lesions-to allow } \\
\text { adequate depth for a durable } \\
\text { restoration }\end{array}$ \\
\hline No removal & & - No dentine carious tissue removal & \\
\hline $\begin{array}{l}\text { Fissure sealant } \\
\text { including "ART } \\
\text { sealants" } \\
\text { (therapeutic) }\end{array}$ & & $\begin{array}{l}\text { - Fissure sealants, place sealants (resins), or glass } \\
\text { ionomer cement over clinically intact enamel or } \\
\text { enamel with signs of early breakdown. This can } \\
\text { also be suitable where there is a microcavitation } \\
\text { but the material is considered to have adequate } \\
\text { mechanical properties to bridge any enamel } \\
\text { breaches. }\end{array}$ & $\begin{array}{l}\text { Primary and permanent teeth } \\
\text { Shallow and moderate } \\
\text { carious lesions that appear } \\
\text { noncavitated clinically, } \\
\text { radiographically they might } \\
\text { extend into dentine }\end{array}$ \\
\hline Hall Technique & & $\begin{array}{l}\text { Preformed (stainless steel) crown is cemented } \\
\text { over the primary molar tooth to seal dentine } \\
\text { carious lesions }\end{array}$ & $\begin{array}{l}\text { Primary teeth } \\
\text { Moderate }{ }^{\mathrm{a}} \text { and deep } \\
\text { noncavitated and cavitated } \\
\text { proximal carious lesions, } \\
\text { radiographically-"clear" } \\
\text { band of dentine between } \\
\text { carious lesion and pulp } \\
\text { Permanent teeth } \\
\text { Not indicated }\end{array}$ \\
\hline $\begin{array}{l}\text { Nonrestorative } \\
\text { cavity control }\end{array}$ & $\begin{array}{l}\text { Nonrestorative caries treatment, } \\
\text { nonoperative caries treatment } \\
\text { and prevention, slicing technique }\end{array}$ & $\begin{array}{l}\text { - Cavitated dentine carious lesions are } \\
\text { transformed to cleansable forms that can be } \\
\text { cleaned by the patient or parent/carer with a } \\
\text { toothbrush } \\
\text { - May or may not be supported by regular } \\
\text { fluoride varnish application or placement of glass } \\
\text { ionomer-based material }\end{array}$ & $\begin{array}{l}\text { Primary and permanent teeth } \\
\text { Cavitated dentine carious } \\
\text { lesions that can be made } \\
\text { cleansable; might not be } \\
\text { restorable (for permanent } \\
\text { teeth, might also be suitable } \\
\text { for root surface caries) }\end{array}$ \\
\hline $\begin{array}{l}\text { Selective removal to } \\
\text { soft dentine }\end{array}$ & $\begin{array}{l}\text { Partial, incomplete, minimally } \\
\text { invasive, or ultraconservative } \\
\text { caries removal }\end{array}$ & $\begin{array}{l}\text { - Pulpally, remove carious tissue until soft dentine } \\
\text { is reached } \\
\text { - Enough tissue is removed to place a durable } \\
\text { restoration avoiding pulp exposure } \\
\text { - Periphery of cavity, clean to hard dentine } \\
\text { (similar to sound dentine) }\end{array}$ & $\begin{array}{l}\text { Primary and permanent teeth } \\
\text { Deep carious lesions }{ }^{\mathrm{b}}\end{array}$ \\
\hline $\begin{array}{l}\text { Selective removal to } \\
\text { firm dentine }\end{array}$ & $\begin{array}{l}\text { Partial caries removal, minimally } \\
\text { invasive, or incomplete caries } \\
\text { removal }\end{array}$ & $\begin{array}{l}\text { - Pulpally, remove carious tissue until leathery } \\
\text { or firm dentine (resistant to hand excavator) is } \\
\text { reached } \\
\text { - Periphery of cavity, clean to hard dentine } \\
\text { (similar to sound dentine) }\end{array}$ & $\begin{array}{l}\text { Primary and permanent teeth } \\
\text { Shallow and moderate dentine } \\
\text { carious lesions }{ }^{\mathrm{a}} \text { to allow } \\
\text { adequate depth for a durable } \\
\text { restoration }\end{array}$ \\
\hline Stepwise removal & $\begin{array}{l}\text { Stepwise caries removal, stepwise } \\
\text { excavation, 2-step caries } \\
\text { removal }\end{array}$ & $\begin{array}{l}\text { - Pulpally, selective removal to soft dentine during } \\
\text { first step-remove carious tissue until soft } \\
\text { dentine is reached } \\
\text { - Enough tissue is removed to place a durable } \\
\text { restoration avoiding pulp exposure } \\
\text { - Periphery of cavity, clean until hard dentine is } \\
\text { reached (similar to sound dentine) } \\
\text { Subsequently (6 to } 12 \mathrm{mo} \text { ) } \\
\text { - Pulpally, selective removal to firm dentine and } \\
\text { place a long-term restoration }\end{array}$ & $\begin{array}{l}\text { Primary teeth } \\
\text { Not indicated-use selective } \\
\text { removal to soft dentine } \\
\text { Permanent teeth } \\
\text { Deep carious lesions }\end{array}$ \\
\hline $\begin{array}{l}\text { Nonselective to } \\
\text { hard dentine (not } \\
\text { advocated) }\end{array}$ & Complete caries removal & $\begin{array}{l}\text { Pulpally and cavity periphery-carious tissue } \\
\text { removal aims to remove all demineralized } \\
\text { dentine to reach hard dentine, leaving no } \\
\text { softened dentine } \\
\text { - Considered overtreatment }\end{array}$ & $\begin{array}{l}\text { Primary and permanent teeth } \\
\text { Not advocated }\end{array}$ \\
\hline
\end{tabular}

${ }^{a}$ Shallow and moderate lesions are those involving the outer pulpal two-thirds or three-quarters of dentine radiographically or where there is no risk of pulp exposure.

${ }^{b}$ Deep lesions are defined as those radiographically involving the inner pulpal third or quarter of dentine or with clinically assessed risk of pulpal exposure. 
Table 2. The 42 Terms for Carious Tissue Removal/Management Techniques Derived through Structured Literature Searching and Consultation within the International Caries Consensus Collaboration.

\begin{tabular}{|c|c|}
\hline Arrestment of caries lesion in dentin & Nonrestorative caries treatment \\
\hline ART & Nonrestorative therapy \\
\hline Atraumatic restorative treatment & Nonsurgical caries management \\
\hline Caries control achieved & One-step complete caries removal \\
\hline Complete caries removal & One-step incomplete excavation \\
\hline Complete excavation & Partial caries removal \\
\hline Conservative treatment of deep caries lesions & Partial excavation \\
\hline Incomplete caries removal & Sealing in caries lesion \\
\hline Incomplete excavation & Sealing in caries \\
\hline Indirect pulp cap & Sealing in caries "using restorative materials/techniques" (resins, crowns, etc.) \\
\hline Minimally invasive caries removal & Sealing in caries using "nonrestorative caries treatment" (e.g., sealants, infiltration) \\
\hline Minimally invasive indirect pulp therapy technique & Selective \\
\hline Minimally invasive operative approach & Selective excavation \\
\hline Minimally invasive operative caries management & Stepwise \\
\hline Minimum intervention dentistry & Stepwise caries removal \\
\hline No caries removal & Stepwise excavation \\
\hline No dentinal caries removal & Surgical \\
\hline Noninvasive management of caries lesions & Two-step complete excavation \\
\hline Nonmechanical removal of carious tissue & Two-step incomplete excavation \\
\hline Nonoperative caries treatment and prevention & $\begin{array}{l}\text { Ultraconservative treatment (cleaning sizable cavities with brush and paste in } \\
\text { primary teeth) and small cavities restored with ART }\end{array}$ \\
\hline Nonoperative management of caries lesion (arrest of caries lesion) & Unselective \\
\hline
\end{tabular}

of technique in a research study is found in the 10-y follow-up report of the seminal ultraconservative caries removal study by Mertz-Fairhurst and coworkers (1998), in which there were 2 control groups with conventional restorations and 1 intervention arm where no soft dentine was removed:

We removed all of the crumbly, opaque demineralized enamel with a bur until we reached translucent sound enamel. We did not remove undermined enamel or caries below the bevel. . . . [We] observed shreds of carious dentin or other material hanging below the bevel toward the soft and wet pulpal floor of the cavity. A layer of soft and wet-looking dentine in the pulpal area of the cavity remained intact, and there was absolutely no instrumentation below the enamel bevel.

Consistency, accuracy, and precision are important for terminology to be used successfully, which means there has to be standardization globally. One of the crucial aspects of this consensus work is that there is widespread dissemination and uptake, and to do this, there has to be agreement that these are acceptable terms, across a broad range of communities and groups. The cosmopolitan nature of the ICCC means that views have been represented from 12 countries. To further assist with uptake of the terminology and its dissemination, we are linking with the European Organisation for Caries Research, the International Association for Dental Research Cariology Group, and the American Dental Education Association Cariology Section. Expertise sharing, experience, and joining with educational forums are part of the dissemination strategy to assist in the ultimate goal of uptake and use of the ICCC terminology recommendations across the spectrum of researchers, clinicians, and educators.

\section{How Much of a Problem Is the Current Terminology? Scoping and Consensus Methodology}

In a methodical search for systematic reviews comparing different methods of caries removal (including partial caries removal, no caries removal, etc.), 7 systematic reviews were identified (Griffin et al. 2008; Thompson et al. 2008; Hayashi et al. 2011; Ferreira et al. 2012; Ricketts et al. 2013; Schwendicke, MeyerLückel, et al. 2013; Schwendicke, Dörfer, et al. 2013). When these and the studies within them were searched for the terminologies used to describe the various carious lesion management strategies, 23 terms were found. These were circulated around the ICCC group members, who were asked to contribute any further terms that were being used, and 19 further unique new terms were added. This gave a total of 42 terms (see Table 2), a large number to describe essentially 4 different parts of the spectrum of carious lesion removal/management.

The terms were circulated again, and this time the ICCC group was asked to choose up to 6 terms most representative of the full spectrum of options for carious tissue removal. Eight approaches to naming were returned with comments. These provided the basis for the discussions at the consensus meeting.

\section{Initial Areas Agreed before Proceeding}

\section{Dental Caries and Carious Lesion}

There was full agreement that dental caries (or simply caries) and carious lesion were not interchangeable terms, although they are often used as such.

There was consensus that dental caries (the pathologic process) cannot be removed, and only carious tissues can be removed. 
An alternative way of viewing this is to consider that the lesion can be stabilized by either noninvasive or invasive means.

Although it is necessary to be exact and specify the definitions for caries and carious, it is worth noting that, in the English language, the pronunciation of these words makes them sound almost identical. However, in other languages this may not be the case.

\section{Caries Management and Carious Lesion Management}

The ICCC group considered 2 terms - caries management and carious lesion management. While the term caries management has historically been used in different ways, often to include the restoration of teeth, it was agreed that it should be limited to situations involving control of the disease through preventive and noninvasive means. Therefore, caries management is a term to describe the actions taken at a patient levelthat is, demineralization and plaque/biofilm being managed not for one specific surface but for the whole person (e.g., plaque control/toothbrushing instruction, fluoride application, dietary interventions, and behavior change techniques). Caries management aims to control the disease and to prevent a lesion from becoming clinically manifest and, for those lesions detectable clinically, prevent their advancement.

What do we call the situation in which patient-level caries management has failed? Consider 2 situations where a carious lesion needs to be managed: first, an active lesion that might require a noninvasive approach, such as biofilm removal or application of fluoride varnish, to limit progression; second, where a lesion is not cleansable and is vulnerable to progression even in the presence of a full preventive program. In both of these cases, carious lesion management is aimed at controlling the symptoms of the disease at a tooth level. Of course, there is still a need for caries management to take place at a patient level to stem the source of the problem (the cause of the cause). However, for the purposes of this paper, carious lesion management means any procedure that involves doing something to an established, noncleansable carious lesion to stop its progression. This might involve removing none, some, or all of the carious tissues from a noncleansable lesion.

\section{Removal of Carious Tissues}

The term removal was preferred to excavation, to avoid the synonymous link (in English) with hand excavation instrumentation and spoon excavators. It was agreed that the word excavation implied (albeit to a minor extent) that the process was inextricably linked to hand excavation of carious lesions and could possibly limit the generalizability of the term.

\section{Guiding Principles of Caries Tissue Removal}

The ICCC group agreed on the primary aim of carious tissue removal:

- To retain the tooth and the health (sensibility/vitality) of its pulp for as long as possible
The guiding principles of carious tissue removal are as follows:

- Preservation of dental tissues

- Maintenance of pulpal health

- Avoidance of pulp exposure

- Avoidance of dental anxiety (often considered particularly important in children but should be considered for all patients)

- Provision of sound cavity margins to achieve a peripheral seal

\section{Complete Removal of Carious Tissues}

Through discussion, the group became aware that the term complete, when referring to removal of carious tissues, held different meanings for different people. While within the group, this term was considered to mean "removal until only leathery or firm dentine (resistant to hand excavator) is left pulpally," it was acknowledged that there was still a widely held belief that it meant "removal until only hard dentine is left pulpally." From the systematic reviews of the literature that were evaluated, the group considered removal of carious lesion to leave only hard dentine throughout the cavity to be overtreatment, involving removal of tooth tissue that did not need to be removed (Thompson et al. 2008; Ricketts et al. 2013; Schwendicke, Meyer-Lückel, et al. 2013). It was also agreed that although the words firm and hard are subjective, they were the best terms available.

\section{Terminology for Approaches to Carious Tissue Removal}

In describing the clinical manifestations of caries, it would be ideal to relate the visual appearance directly to what is taking place histopathologically (Ogawa et al. 1983; Ngo et al. 2006; Wambier et al. 2007; Chibinski et al. 2013; Corralo and Maltz 2013). However, this is not straightforward. Histopathologic micro- and ultrastructural investigations of the relationship between the visual appearance of carious tooth tissue and parameters such as bacterial invasion, degree of demineralization, and softness of dentine have been central to developing an understanding of the caries process. One historical example of misinterpretation of histopathology leading to overexcavation was the belief that early lateral spread of demineralized dentine, undermining sound subjacent enamel, led to cavitation of enamel (Silverstone and Hicks 1985). To manage this clinically, early operative intervention was suggested, including the concept of the tunnel preparation (Wilson and McLean 1988). However, more recent research has clarified the structural interrelations, confirming that the spread of contaminated dentine is a sequela of the clinically exposed dentine lesion (Bjørndal and Thylstrup 1995; Ekstrand et al. 1998). The lateral contamination of dentine appears strictly related to stages of retrograde demineralization of enamel (Bjørndal and Kidd 2005); that is, demineralization of the enamel originates at the enamel-dentinal junction as a result of bacterial metabolic activity within the dentinal lesion. Interestingly, the increasing 


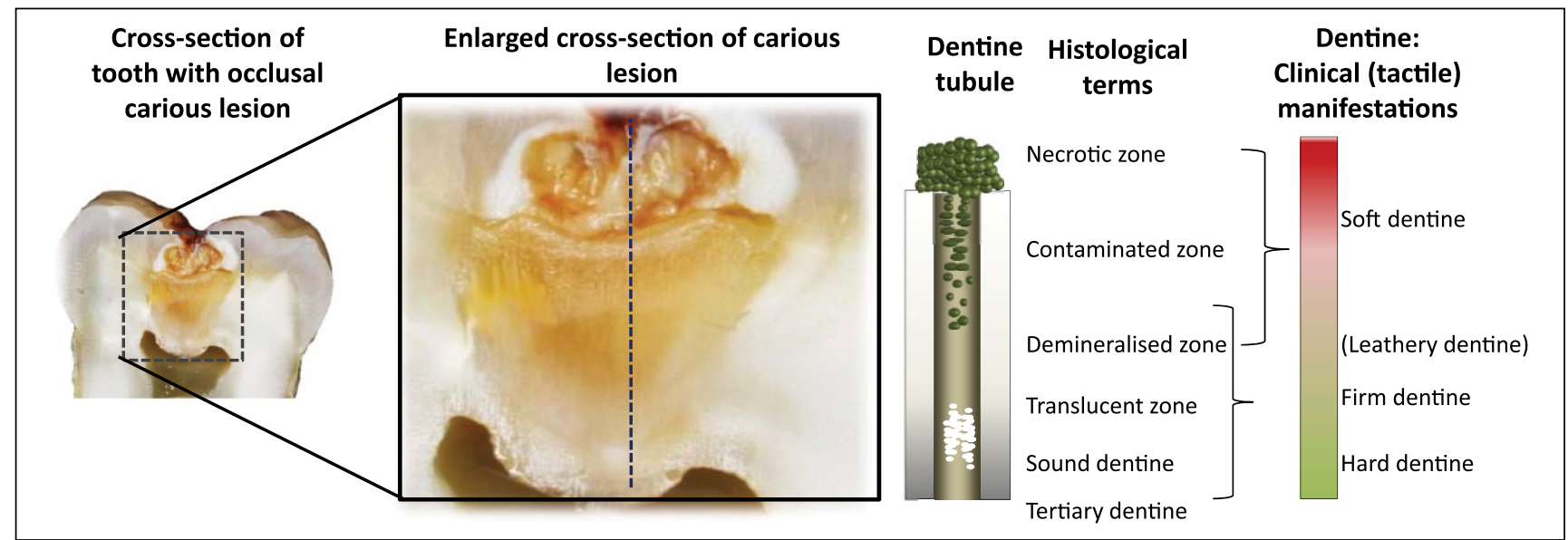

Figure. Diagrammatic representation of the carious lesion (after Ogawa et al. 1983).

use of clinical magnification technologies has led to these socalled histopathologic features being visible at the clinical level. Traditionally, these histologic terms are less helpful when communicating to dentists in clinical settings and attempting to describe the degree to which carious tissues should be removed. In addition, it was felt that some of the terms (e.g., infected) were outdated and conveyed the idea that dental caries was a communicable disease. The terms shown in the Figure, for the clinical (tactile) manifestations of carious dentine, were agreed, and we have attempted to link the clinical consequences to the histologic terms as far as possible. Table 1 expands on this by showing these agreed terms and their relationship to previously used terms.

\section{Definitions for Different Clinical Presentations of Dentine: Soft, Leathery, Firm, and Hard}

In material sciences, hardness can be characterized by the ability of a harder material to make a mark or to scratch a softer one. The force necessary to cause the scratch is also important. For practical purposes, a combination of these is probably the best way for the clinical dentist to determine how "soft" or "hard" dentine is, and some guidance is given below to describe the physical properties that are associated with different states of dentine.

\section{Soft Dentine}

Soft dentine will deform when a hard instrument is pressed onto it and can be easily scooped up (e.g., with a sharp hand excavator) with little force being required.

\section{Leathery Dentine}

Although the dentine does not deform when an instrument is pressed onto it, leathery dentine can still be easily lifted without much force being required. There may be little difference between leathery and firm dentine, with leathery being a transition on the spectrum between soft and firm dentine.

\section{Firm Dentine}

Firm dentine is physically resistant to hand excavation, and some pressure needs to be exerted through an instrument to lift it.

\section{Hard Dentine}

For hard dentine, a pushing force needs to be used with a hard instrument to engage the dentine, and only a sharp cutting edge or a bur will lift it. A scratchy sound or "cri dentinaire" can be heard when a straight probe is taken across the dentine.

\section{Definitions of Approaches to Carious Tissue Removal}

\section{Atraumatic Restorative Treatment}

Atraumatic restorative treatment was agreed to mean a specific technique that encompassed a mechanism for carious lesion management using hand instruments only, through removing soft, completely demineralized enamel and dentine until firm resistance is felt (see Selective Removal of Carious Tissue below). The cavity is then restored and available pits and fissures are sealed with an adhesive dental material, usually a high-viscosity glass ionomer cement. For deep lesions (reaching into the inner pulpal third of dentine on radiograph), some soft carious tissue should be left on the pulpal wall to avoid pulp exposure. Therefore, the decision to carry out selective removal to firm dentine or to soft dentine (see below) is related to cavity depth and the possibility of pulp exposure.

\section{No Removal: No Dentine Carious Tissue Removal}

There are various procedures where no dentine carious tissue removal takes place. Although diverse methods are used to carry this out, these procedures effectively serve the same purpose - to control the carious lesion without removing any of the diseased dentine tissue. The following techniques have been included under the "no carious tissue removal" banner. 
Resin or glass ionomer sealant materials. Pit and fissure therapeutic sealant materials (resin or high-viscosity glass ionomer cements) can be placed over enamel and dentine carious lesions. However, particularly with unfilled resin, mechanical properties are limited for filling and covering microcavities in enamel. There are also theoretical concerns about the materials' abilities to resist forces occlusally when there is a considerable amount of soft dentine beneath the weakened enamel (the "trampoline" effect). Therefore, the extent of the lesions where these materials can be used may be limited, pending evidence, to lesions that are confined (on a radiograph) to the outer third of dentine.

The Hall Technique. This is a specific procedure for primary molars where a preformed metal crown (stainless steel) is fitted over the tooth to seal dentine carious lesions. The crown is cemented with glass ionomer cement over a primary molar tooth and carious lesion with no tooth preparation or carious lesion removal. It is usually indicated for approximal lesions. The crown effectively seals the dentine carious lesion and slows down or prevents its progression to the dental pulp, allowing the primary molar to exfoliate without pain or infection.

Nonrestorative cavity control. Other names for techniques (though differing slightly) that would be encompassed within this strategy include nonoperative caries treatment and prevention (Vermaire et al. 2014), nonrestorative caries treatment (Lo et al. 1998; Gruythuysen 2010; Mijan et al. 2014), and slicing preparations.

These techniques are broadly similar in that they aim to achieve arrest of a carious lesion using a package of care, through caries management at a patient level. They aim to prevent further loss of tooth tissue through caries progression in a cleansable cavity by successful instigation of an intensive preventive regimen that includes plaque removal through toothbrushing with a fluoridated toothpaste and/or application of fluoride varnish. From a carious lesion perspective, it may be necessary to alter the shape of the cavity by opening the cavity margins, to allow it to be cleansable, and thus might involve some operative, although not restorative, intervention. These methods tend to be particularly applied to primary teeth but have a role in the permanent dentition, for example, in root carious lesions.

\section{Selective Removal of Carious Tissue}

Terms previously used for nonselective and selective removal of carious tissues have commonly included complete and incomplete excavation of carious lesions. These describe the result at the end of the carious tissue removal process. There are 3 problems with these terms:

1) The criteria that demarcate the extent to which carious tissues are removed have not been defined or agreedshould this be "free from bacteria," "demineralized dentine," "discoloured dentine," or "soft dentine"?

2) There are no commonly used and easily accessible technologies available to reliably assess any of these criteria in a clinical setting, although it is acknowledged that this might change in the future.

3) If clinical assessments are reevaluated through more advanced techniques (measurement of bacterial load or mineral loss) based on the findings of previous research, it is most likely that areas of dentine will be found where there is incompletely removed carious tissue after attempted complete removal and vice versa.

Thus, we felt that it made more sense to use procedural definitions to describe exactly what has been done, instead of measuring what we attempted to achieve. Using this rationale, the group agreed on the term selective removal. In selective removal, different excavation criteria are used when assessing the periphery of the cavity to the area in close proximity to the pulp. The periphery of the cavity should be surrounded by "sound" enamel to allow the best adhesive seal. The peripheral dentine should be hard - with similar tactile characteristics to sound dentine, such as a scratching noise when scraping the surface with a sharp hand excavator or dental probe. However, firm carious tissue should be left toward the pulpal aspect of the cavity, with enough of it removed to allow a durable bulk of restoration to be placed while avoiding pulp exposure. For deep lesions, extending beyond the inner (pulpal) third or quarter of the dentine radiographically, selective removal should be to soft dentine; the main aim is not to expose or irritate the pulp, provided that there are no clinical symptoms of pulp inflammation present. For less deep lesions, selective removal should take place to firm dentine pulpally; this is likely to be necessary to allow adequate depth for the restorative material bulk.

There were other reasons that the term selective removal was supported. The group agreed that there was an advantage to using terms that had not yet been used in the literature. This was the case here, where multiple terms for a single procedure were used across different groups and where the definition behind them was not clear. In addition, the negative association of the terms partial and incomplete, which implied that the whole required treatment had not been carried out and that treatment was suboptimal, were considered disadvantageous in supporting the procedures' adoption and acceptance as standard techniques.

A description of these terms is found below.

Selective removal to soft dentine. Selective removal to soft dentine in deep lesions means leaving soft carious dentine in the pulpal aspect of the cavity. Peripheral enamel and dentine should be hard at the end of excavation to allow the best adhesive seal. This technique has been known as partial caries, 1-step, ultraconservative, or incomplete caries removal. A sharp hand excavator can be used to check the softness/hardness of the remaining dentine; remember that soft dentine will deform when an instrument is pressed onto it and little force would be required to lift it.

Selective removal to firm dentine. In selective removal to firm dentine, the aim is to excavate to leathery or firm dentine 
(physically resistant to hand excavator) in the pulpal aspect of the cavity. This is the contemporary understanding of how much should be removed if the entire carious - contaminated but not the demineralized dentine, which can be remineralized (Fig.) - is aimed at being removed. It is acknowledged that there are not easily accessible or widely used means to tell when contaminated tissue has been removed and to determine when what is seen in the cavity is only demineralized dentine. However, although somewhat subjective, the tactile sense of reaching firm dentine on the pulpal floor, rather than aiming for hard dentine, is probably the best guide that can be given.

\section{Stepwise Removal}

Certain terms were felt to be in fairly common use; they had less variability in their definition and understanding and were well accepted. It was therefore considered to be advantageous to adopt these as standard with just a clear and unambiguous explanation of the definition behind them. This was the case for stepwise removal (Bjørndal et al. 1997; Bjørndal and Larsen, 2000; Paddick et al. 2005).

Stage I: Selective removal to soft dentine. Stage 1 has the same carious tissue removal aims as selective removal to soft dentine, with completely demineralized carious tissue, still soft, being left pulpally, but where there is removal of enough carious tooth tissue to place a durable restoration while avoiding pulp exposure. The periphery of the cavity should be hardwith similar appearance and tactile characteristics to sound dentine. A provisional restoration is placed with a restorative material that is considered suitable to last up to $12 \mathrm{mo}$.

Stage 2: Selective removal to firm dentine 6 to 12 mo later. The subsequent removal of this provisional restoration should then be followed by the stage 2 pathway, selective removal to firm dentine, with placement of a definitive restoration aiming for longevity. This technique has been known as 2-step excavation.

\section{Nonselective Removal to Hard Dentine}

Nonselective removal to hard dentine was formerly known as complete excavation or complete caries removal and is no longer recommended as an approach for carious tissue removal. It is only mentioned here for completeness. It is the approach to carious tissue removal that was accepted in the past and is now considered overtreatment. The aim was to remove soft carious tissue to reach hard dentine resembling healthy dentine in all parts of the cavity, including pulpally. For the pulpal area, Bjørndal et al. (2010) describe complete caries excavation as "leaving only central yellowish or greyish hard dentin (equal to the hardness of sound dentin, as judged by gentle probing)." However, for deep caries lesions (reaching into the inner pulpal third of dentine on radiograph), complete caries excavation is now considered likely to result in detriment to the tooth through exposure of the pulp - specifically, indirect damage to the pulp from irritation passing through the thin, remaining dentine thickness or from weakening the tooth's structural integrity unnecessarily (Ricketts et al. 2013; Schwendicke, MeyerLückel, et al. 2013). This approach is no longer recommended.

\section{Summary}

We have presented here a comprehensive list of terms to encompass the full spectrum of carious tissue removal options following a process of consensus and consultation. However, other areas remain where there is no standardized terminology or where there are subjective terms that are commonly used, such as invasive, restorative, and intervention, and we have had to resort to using some of these here and in the parallel paper to this one on recommendations for managing carious lesions (Schwendicke et al. 2016). These will perhaps form the next stage of standardization, but in the meantime there is a need to facilitate dissemination - this is an inextricable and essential component of consensus within the specialty if the advantages of the consensus terminology are to be maximized.

\section{Author Contributions}

N.P.T. Innes, J.E. Frencken, F. Schwendicke, contributed to conception, design, data acquisition, analysis, and interpretation, drafted and critically revised the manuscript; L. Bjørndal, M. Maltz, D.J. Manton, D. Ricketts, K. Van Landuyt, A. Banerjee, G. Campus, S. Doméjean, M. Fontana, S. Leal, E. Lo, V. Machiulskiene, A. Schulte, C. Splieth, A.F. Zandona, contributed to conception, design, data acquisition, analysis, and interpretation, critically revised the manuscript. All authors gave final approval and agree to be accountable for all aspects of the work.

\section{Acknowledgments}

The ICCC thanks Lisbet Brike and Amy Caldwell-Nichols for organizing travel and accommodation for the conference in Leuven and to Amy Caldwell-Nichols for additional document and manuscript preparation support. Thank you also to GC for the use of its premises in Leuven. Grateful thanks also go to Professor Edwina Kidd, for her presentation, invaluable discussions at the meeting in Leuven, input into improving this manuscript, and, finally, for so generously sharing her wisdom and experience. We thank Professor Wolfgang Buchalla for his contribution to the meeting and discussions on the composition of the manuscripts, and we respect his decision not to support their content through authorship. The conference was kindly sponsored by GC Europe (Leuven, Belgium), DMG (Hamburg, Germany), 3M Espe (Seefeld, Germany), and Dentsply DeTrey (Konstanz, Germany). The sponsors had no role in the design or conduct of the conference or the content of this manuscript and were not present during the conference. Travel to the meeting and accommodation for L.B., W.B., S.D., E.K., M.M., D.J.M., K.V.L., A.B., G.C., M.F., S.L., E.L., V.M., A.S., C.S., and A.Z. were supported by the sponsors. No honoraria were given to any of the participants. The corresponding author formally requested a declaration of possible conflicts of interest from each of the consensus conference members. For the purposes of transparency, we have listed a comprehensive declaration of interests: A.B.-commercial grant: GSK, 3MESPE, paid lectures: 3MESPE, GC, Septodont, Colgate, 
OralB; A.S.-none; A.Z.-paid lectures, ICDAS Foundation member; C.S.-none; D.J.M.-commercial grants: GC, paid lectures: GC, DMG; D.R.-none; E.L.-none; F.S.-commercial grant: DMG, GC, paid lectures and consultancy work: DMG; G.C.-none; J.E.F.- paid lectures: 3MESPE India and GC America; K.V.L.—none; L.B.- none; M.F.—none; M.M.—none; N.P.T.I.- commercial grant: 3MESPE (2001) and paid lectures: 3MESPE, Colgate; S.D.-none; S.L.-paid lectures: GC; V.M.none. The authors declare no other potential conflicts of interest with respect to the authorship and/or publication of this article.

\section{References}

Banerjee A, Doméjean S. 2013. The contemporary approach to tooth preservation: minimum intervention (MI) caries management in general practice. Prim Dent J. 2(3):30-37

Bjørndal L, Kidd EA. 2005. The treatment of deep dentine caries lesions. Dent Update. 32(7): 402-4, 407-410, 413.

Bjørndal L, Larsen T. 2000. Changes in the cultivable flora in deep carious lesions following a stepwise excavation procedure. Caries Res. 34(6):502 508.

Bjørndal L, Larsen T, Thylstrup A. 1997. A clinical and microbiological study of deep carious lesions during stepwise excavation using long treatment intervals. Caries Res. 31(6):411-417.

Bjørndal L, Reit C, Bruun G, Markvart M, Kjældgaard M, Näsman P, Thordrup M, Dige I, Nyvad B, Fransson H, et al. 2010. Treatment of deep caries lesions in adults: randomized clinical trials comparing stepwise vs. direct complete excavation, and direct pulp capping vs. partial pulpotomy. Eur J Oral Sci. 118(3):290-297.

Bjørndal L, Thylstrup A. 1995. A structural analysis of approximal enamel caries lesions and subjacent dentin reactions. Eur J Oral Sci. 103(1):25-31.

Chibinski AC, Reis A, Kreich EM, Tanaka JL, Wambier DS. 2013. Evaluation of primary carious dentin after cavity sealing in deep lesions: A 10- to 13-month follow-up. Pediatr Dent. 35(3):E107-E112.

Corralo DJ, Maltz M. 2013. Clinical and ultrastructural effects of different liners/restorative materials on deep carious dentin: a randomized clinical trial. Caries Res. 47(3):243-250.

Ekstrand KR, Ricketts DN, Kidd EA. 1998. Do occlusal carious lesions spread laterally at the enamel-dentin junction? A histolopathological study. Clin Oral Investig. 2(1):15-20.

Elderton RJ. 1993. Overtreatment with restorative dentistry: when to intervene? Int Dent J. 43(2):17-24

Fejerskov O, Larsen MJ. 2015. Demineralization and remineralisation: the key to understanding clinical manifestations of dental caries. In: Fejerskov O, Nyvad B, Kidd E, editors. Dental caries: the disease and its clinical management. 3rd ed. Oxford (UK): Wiley Blackwell. p. 160-169.

Ferreira JM, Pinheiro SL, Sampaio FC, de Menezes VA. 2012. Caries removal in primary teeth: a systematic review. Quintessence Int. 43(1):e9-e15.

Franzon R, Guimaraes LF, Magalhaes CE, Haas AN, Araujo FB. 2014. Outcomes of one-step incomplete and complete excavation in primary teeth: a 24-month randomized controlled trial. Caries Res. 48(5):376-383.

Frencken JE. 2014. The state-of-the-art of ART restorations. Dent Update. 41(3):218-220, 222-224.

Frencken JE, Peters MC, Manton DJ, Leal SC, Gordan VV, Eden E. 2012 Minimal intervention dentistry for managing dental caries - a review: report of a FDI task group. Int Dent J. 62(5):223-243.

Fusayama T. 1997. The process and results of revolution in dental caries treatment. Int Dent J. 47(3):157-166.

Green D, Mackenzie L, Banerjee A. 2015. Minimally invasive long term management of direct restorations: The "5rs." Dent Update. 42(5):413-426.

Griffin SO, Oong E, Kohn W, Vidakovic B, Gooch BF; CDC Dental Sealant Systematic Review Work Group, Bader J, Clarkson J, Fontana MR, Meyer
DM, Rozier RG, Weintraub JA, Zero DT. 2008. The effectiveness of sealants in managing caries lesions. J Dent Res. 87(2):169-174.

Gruythuysen R. 2010. Non-restorative cavity treatment: managing rather than masking caries activity. Ned Tijdschr Tandheelkd. 117(3):173-180.

Hayashi M, Fujitani M, Yamaki C, Momoi Y. 2011. Ways of enhancing pulp preservation by stepwise excavation: a systematic review. J Dent. 39(2):95-107.

Hesse D, Bonifácio CC, Mendes FM, Braga MM, Imparato JC, Raggio DP. 2014. Sealing versus partial caries removal in primary molars: a randomized clinical trial. BMC Oral Health. 14:58.

Innes NP, Evans DJ. 2013. Modern approaches to caries management of the primary dentition. Brit Dent J. 214(11):559-566.

Kidd EA, Bjørndal L, Fejerskov O. 2015. Caries removal and the pulpo-dental complex. In: Fejerskov O, Nyvad B, Kidd E, editors. Dental caries: the disease and its clinical management. 3rd ed. Oxford (UK): Wiley Blackwell. p. 376-386.

Lo EC, Schwarz E, Wong MC. 1998. Arresting dentine caries in Chinese preschool children. Int J Paed Dent. 8(4):253-260.

Maltz M, Garcia R, Jardim JJ, De Paula LM, Yamaguti PM, Moura MS, Garcia F, Nascimento C, Oliveira A, Mestrinho HD. 2012. Randomized trial of partial vs. stepwise caries removal: 3 years follow-up. J Dent Res. 91(11):1026-1031.

Mertz-Fairhurst EJ, Curtis JW Jr, Ergle JW, Rueggeberg FA, Adair SM. 1998. Ultraconservative and cariostatic sealed restorations: results at year 10 J Am Dent Assoc. 129(1):55-66.

Mijan M, de Amorim RG, Leal SC, Mulder J, Oliveira L, Creugers NH, Frencken JE. 2014. The 3.5-year survival rates of primary molars treated according to three treatment protocols: a controlled clinical trial. Clin Oral Investig. 18(4):1061-1069.

Ngo HC, Mount G, Mc Intyre J, Tuisuva J, Von Doussa RJ. 2006. Chemical exchange between glass-ionomer restorations and residual carious dentine in permanent molars: an in vivo study. J Dent. 34(8):608-613.

Ogawa K, Yamashita Y, Ichijo T, Fusayama T. 1983. The ultrastructure and hardness of the transparent of human carious dentin. J Dent Res. 62(1):7-10.

Paddick JS, Brailsford SR, Kidd EA, Beighton D. 2005. Phenotypic and genotypic selection of microbiota surviving under dental restorations. Appl Environ Microbiol. 71(5):2467-2472.

Pitts NB, Stamm JW. 2004. International Consensus Workshop on Caries Clinical Trials (ICW-CCT) - final consensus statements: agreeing where the evidence leads. J Dent Res. 83(suppl):C125-C128.

Ricketts D, Lamont T, Innes NP, Kidd E, Clarkson JE. 2013. Operative caries management in adults and children. Cochrane Database Syst Rev. 3:CD003808.

Schwendicke F, Dörfer CE, Paris S. 2013. Incomplete caries removal: a systematic review and meta-analysis. J Dent Res. 92(4):306-314. Erratum in J Dent Res. 2013;92(8):759.

Schwendicke F, Frencken JE, Bjørndal L, Maltz M, Manton D, Ricketts D, Van Landuyt K, Banerjee A, Campus G, Doméjean S, et al. 2016. Managing carious lesions: consensus recommendations on carious tissue removal Adv Dent Res. 28(2):58-67.

Schwendicke F, Meyer-Lückel H, Dorfer C, Paris S. 2013a. Failure of incompletely excavated teeth: a systematic review. J Dent. 41(7):569-580.

Silverstone LM, Hicks MJ. 1985. The structure and ultrastructure of the carious lesion in human dentin. Gerodontics. 1(4):185-193.

Thompson V, Craig RG, Curro FA, Green WS, Ship JA. 2008. Treatment of deep carious lesions by complete excavation or partial removal: a critical review. J Am Dent Assoc. 139(6):705-712.

Vermaire JH, Poorterman JH, Van Herwijnen L, Van Loveren C. 2014. A threeyear randomized controlled trial in 6-year-old children on caries-preventive strategies in a general dental practice in the Netherlands. Caries Res. 48(6):524-533.

Wambier DS, dos Santos FA, Guedes-Pinto AC, Jaeger RG, Simionato MR. 2007. Ultrastructural and microbiological analysis of the dentin layers affected by caries lesions in primary molars treated by minimal intervention. Pediatr Dent. 29(3):228-234.

Wilson AD, McLean JW. 1988. Glass-ionomer cement. Chicago (IL): Quintessential Publishing Company. p. 179-220. 